\title{
Thermal Analysis of Laptop Battery Using Composite Material
}

\author{
R.Arunkumar \\ Assistant Professor Department of Electrical and Electronics Engineering \\ Alpha College of Engineering and Technology, Puducherry, India
}

\begin{abstract}
The main objective of this paper is to reduce the heat produced in the Battery. A composite material is placed over the battery to absorb the heat produced in the internal cells and outer casing. The temperature of the battery is analyzed using ANSYS15.0 software. The simulation result is compared with the cooling methods of cooling fans, heat sinks and fins. According to the simulation result, the proposed method is better effective in cooling the batteries. Overheating in laptop leads to failure of hardware components and decrease the lifespan of the computer. This thermal management of laptop battery using composite material reduces the temperature up to $47^{\circ} \mathrm{C}$ with better thermal efficiency. Due to the reduction of temperature in the battery, there is a considerable reduction in charging time of the battery and also it avoids the fast discharging in batteries.
\end{abstract}

Keywords: Composite material, cooling fan, heat sink, temperature

\section{Introduction}

A Battery is a device consisting of electrochemical cells which convert chemical energy into electrical energy. It is basically classified into two types primary and secondary. In primary batteries, a chemical reaction takes place at only once, this action cannot be reversed and the battery is discarded. While in secondary batteries, the chemical reaction can be reversed and the battery is rechargeable. They can be recharged by passing an electric current through them. In the modern world, secondary battery plays a vital role in hand phones, laptops, and remote control applications and in hearing aids. Nowadays the use of secondary batteries becomes very common in electrical drives due to the shortage and increase in the price of petroleum products.

Especially in secondary batteries, the lithium ion (Li-ion) batteries are very popular due to the generation of higher voltage than other types of cells, can be made into convenient shapes and sizes, less weight, high energy density, and less self -discharge [1-2]. The main drawback in the secondary battery is the heat production in the internal cells of the battery. The heats produced in the battery reaches up to $60^{\circ} \mathrm{C}$ in the normal working condition and do not have a proper heat transfer or cooling method to reduce the temperature. This heat inside the battery spreads over the internal cells and also it reduces the lifetime of the battery [3-4] and sometimes even leads to an explosion of batteries. The heat produced in the laptop battery not only affects the battery and also leads to several problems and damage in motherboard, hard discs etc. Hence this paper deals with the reduction of temperature produced in the battery using the composite material. This material significantly reduces the temperature inside the battery by absorbing the heat produced inside the battery.

\section{Composite Material}

Composite material [5] is a material with two or more base materials with different physical and chemical properties, when they are combined they produce a different unique characteristic from the base material. Composite materials are chosen as the cooling material to be placed over the laptop battery casing. The materials chosen for analysis are I. Copper II. Aluminum III. Carbon fiber

\begin{tabular}{|c|c|c|c|c|}
\hline S.No & Material & Density & $\begin{array}{c}\text { Thermal } \\
\text { Conductivity }\end{array}$ & Emissivity \\
\hline 01. & COPPER & High & Good & Low \\
\hline 02. & ALUMINIUM & Moderate & Moderate & Low \\
\hline 03. & $\begin{array}{c}\text { CARBON } \\
\text { FIBER }\end{array}$ & Low & Moderate & Moderate \\
\hline
\end{tabular}

Table 1: Material Comparison Table 


\section{Design Of Battery In Cad}

The tabulation below shows the dimensions of the laptop battery. Using the tabulated parameter values the battery is designed in AutoCAD software.

\begin{tabular}{|c|c|c|}
\hline S.no & Specifications & Dimensions \\
\hline 1 & Size of battery (mm) & $\begin{array}{l}\text { X:270.40mm } \\
Y: 27.40 \mathrm{~mm} \\
\text { Z.49.30mm }\end{array}$ \\
\hline 2 & Size of each unit cell $(\mathrm{mm})$ & $43 * 8 * 26.8$ \\
\hline 3 & Size of core region $(\mathrm{mm})$ & 20.63 (diameter) \\
\hline 4 & Thickness of the case (mm) & 2063 \\
\hline 5 & Weight (kg) & $0.36 \mathrm{~kg}(0.79 \mathrm{lb})$ \\
\hline 6 & Voltage & 11.1 Volts \\
\hline
\end{tabular}

Table 2 Dimensions of Battery Model

Using the tabulated battery parameters value shown in table 2, the battery is designed using AUTOCAD designing software.

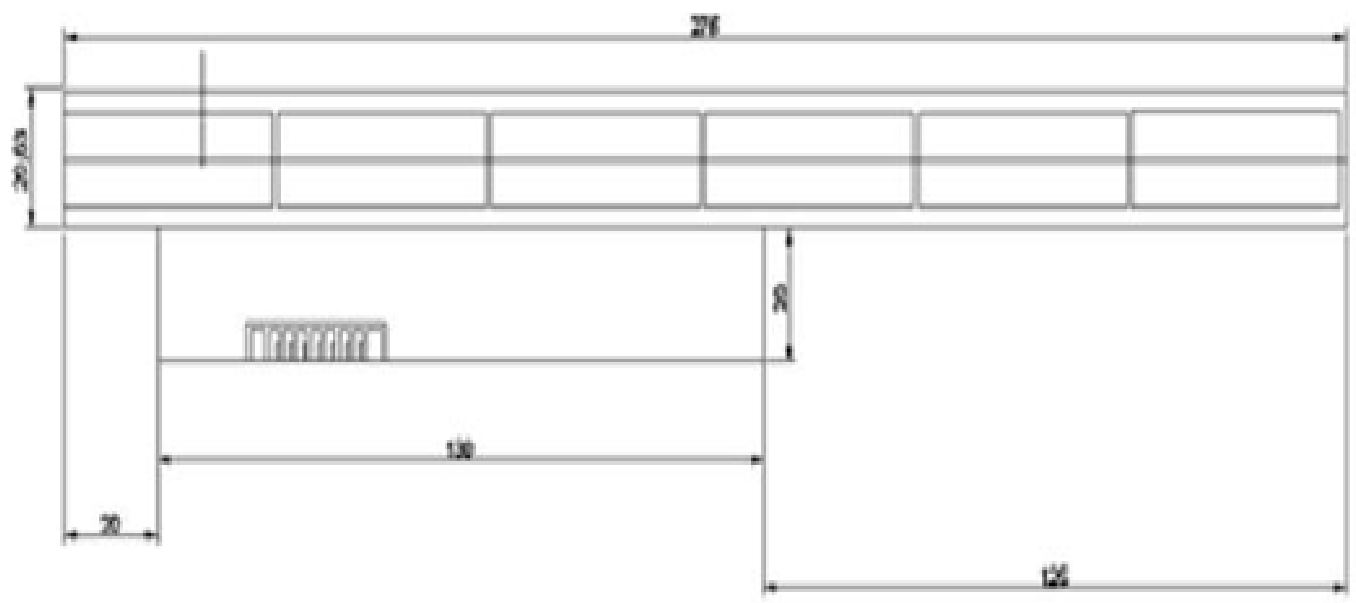

Fig1 Six Cell Laptop Battery Wireframe View

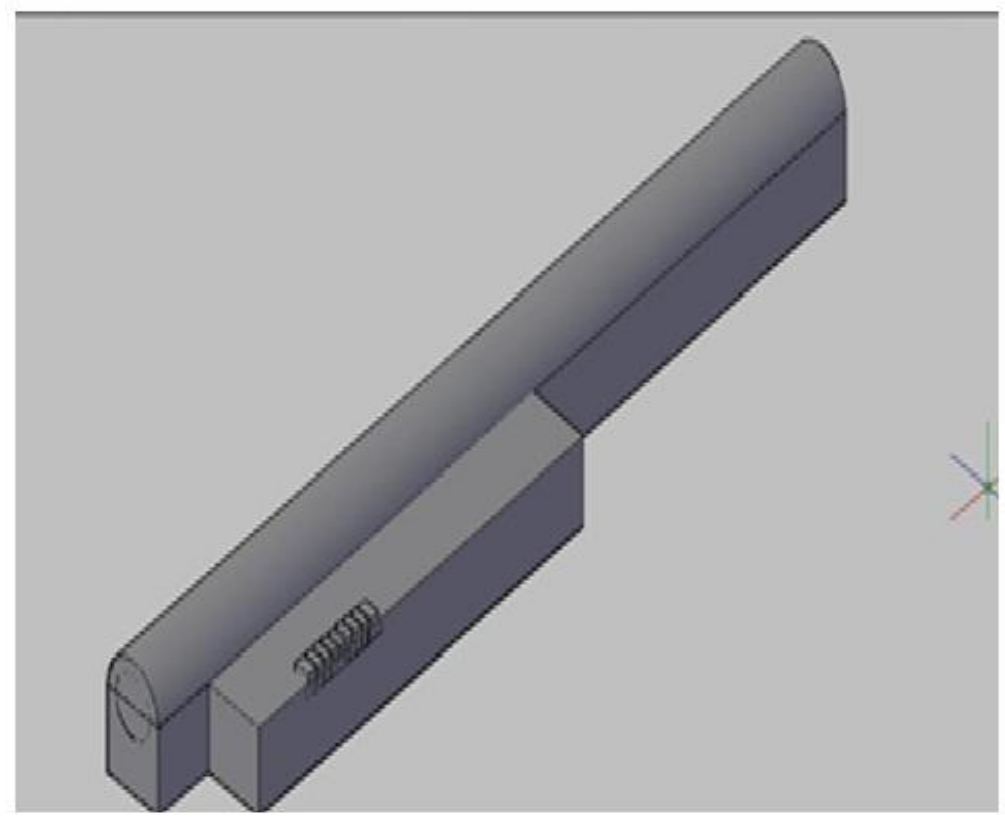

Fig 3 Laptop Battery in 3D Front View 


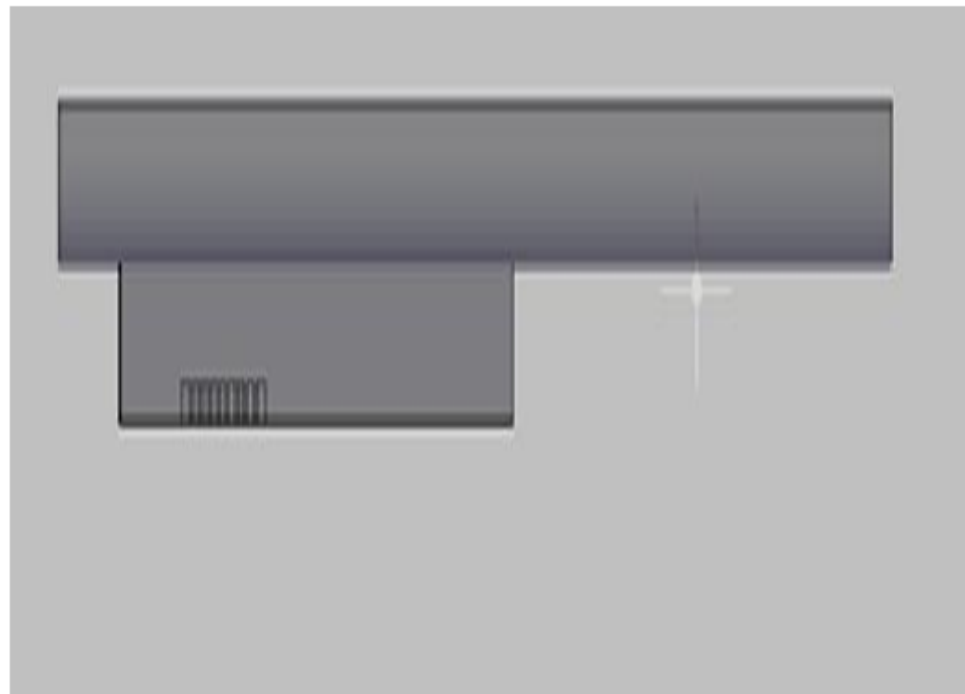

Fig2 Laptop Battery in 3D Isometric View

\section{Boundary Conditions Assigned For Battery}

The boundary condition assigned for battery to analysis the heat transfer over the casing. Overall heat transfer coefficient (U)

$$
\mathrm{U}=\frac{Q}{A\left[T_{a}-T_{b}\right]}
$$

\section{Where}

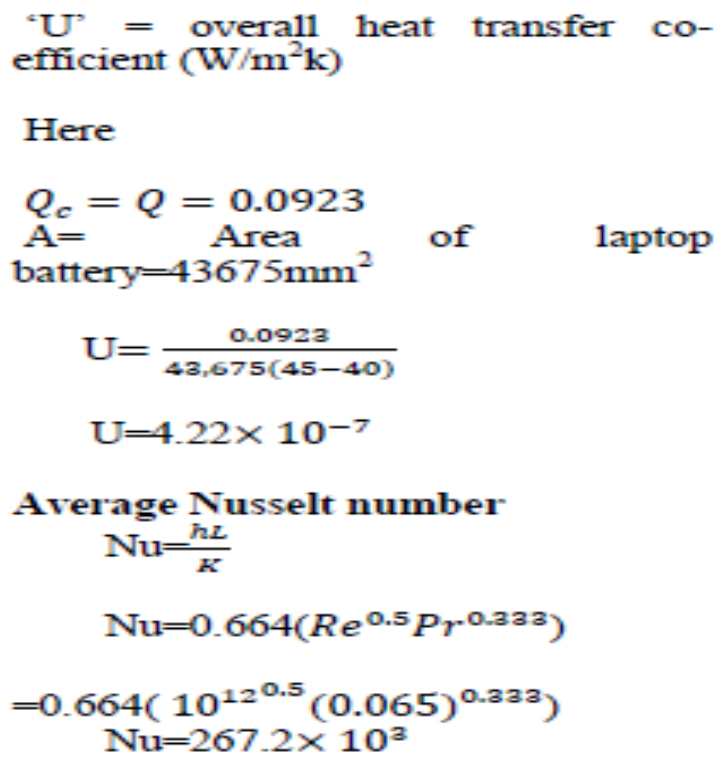

\section{Material Parameter Used In Battery}

In the below table 3 tabulation, The materials which are present inside the laptop battery are listed below from S.No 1-10 and the next remaining 11-13 are the composite materials which are going to be used In the analysis for the battery. 
Thermal Analysis of Laptop Battery Using Composite Material

\begin{tabular}{|c|c|c|c|c|c|}
\hline SL.NO & MATERIAL & DENSITY & $\begin{array}{c}\text { HEAT } \\
\text { CAPACITY }\end{array}$ & $\begin{array}{c}\text { THERMAL } \\
\text { CONDUCTIVITY }\end{array}$ & EMISSITIVITY \\
\hline 1. & $\begin{array}{c}\text { CARBONACEOUS } \\
\text { ELECTRODE }\end{array}$ & 1347.33 & 1437.4 & 1.04 & \\
\hline 2. & $\overline{\mathrm{LICOO} 2}$ & 2328.5 & 1269.21 & 1.58 & \\
\hline 3. & AL FOIL & 2702 & 903 & 238 & \\
\hline 4. & CU FOIL & 8933 & 385 & 398 & \\
\hline 5. & PP SEPARATOR & 1008.98 & 1978.16 & 3344 & \\
\hline 6. & AL-2024 & 2770 & 875 & 170 & $\begin{array}{c}0.25 \text { (OXIDIZED) } \\
0.4 \text { (ROUGH) }\end{array}$ \\
\hline 7. & S.S.AISI-304 & 7900 & 477 & 14.6 & \\
\hline 8. & $\begin{array}{c}\text { LIQUID } \\
\text { ELECTROLYTE }\end{array}$ & 1129.95 & 2055.1 & 0.60 & \\
\hline 9. & COPPER & 8940 & 385 & 398 & \\
\hline 10. & MAGNESIUM & 1770 & 1000 & 96 & \\
\hline 11. & ALUMINIUM & 2710 & 900 & 210 & \\
\hline 12. & COPPER & 8940 & 385 & 398 & \\
\hline 13. & $\begin{array}{l}\text { CARBON } \\
\text { FIBRE }\end{array}$ & 1780 & 1678.3 & $21-180$ & \\
\hline
\end{tabular}

Table 3 Material Parameters

The designed laptop battery and its parameter values are imported in ANSYS 15.0 software. The laptop battery with its side view is shown below,

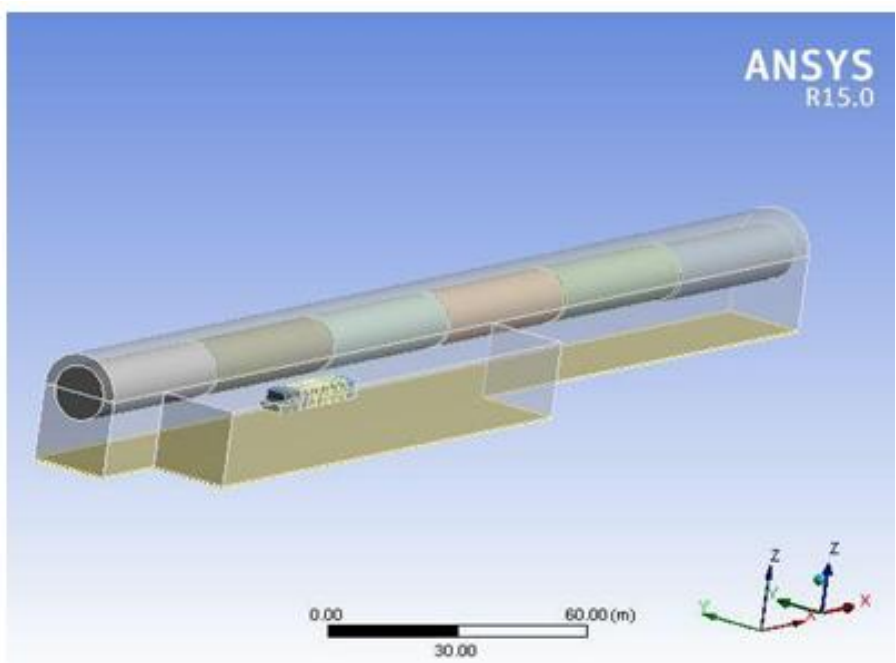

Figure 4 Side view of battery in ANSYS

From the figure, it is seen that the battery temperature is increased from $31^{\circ} \mathrm{C}$ and reaches up to $57^{\circ} \mathrm{C}$ 


\section{RESULT IN ANSYS WITH MATERIAL}

\section{ALUMINIUM}

The simulation is performed by assigning the boundary conditions of the Aluminium material. The simulated result is shown below

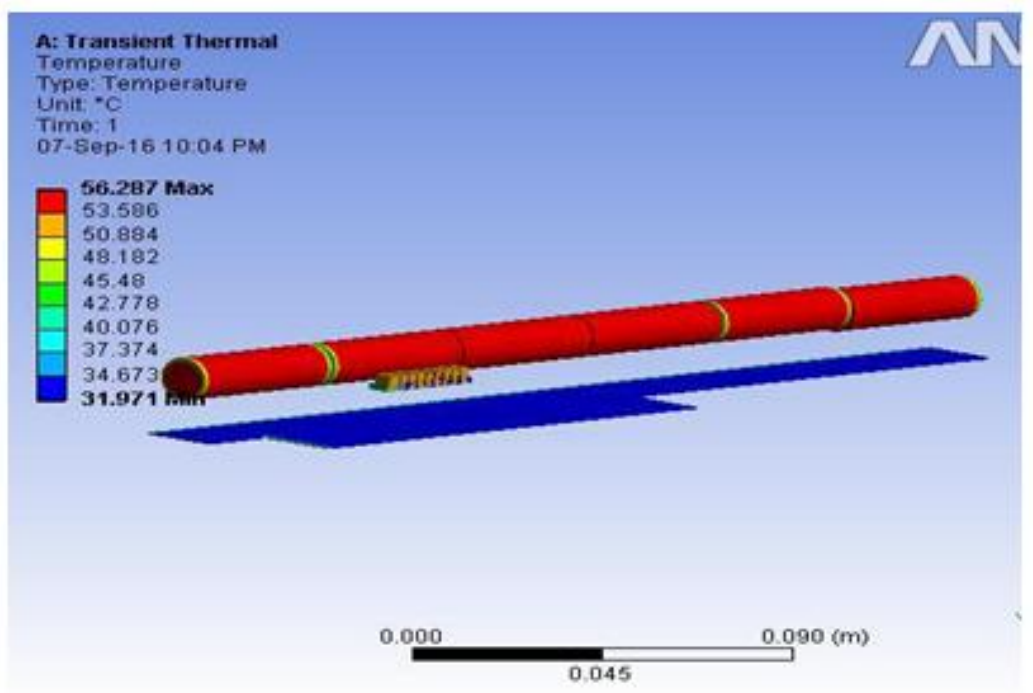

Figure 5 Simulated result of carbon fibber material in ANSYS

\section{RESULT IN ANSYS WITH MATERIAL}

\section{CARBON FIBER}

The simulation is performed by assigning the boundary conditions of the carbon fiber material. The simulated result is shown below

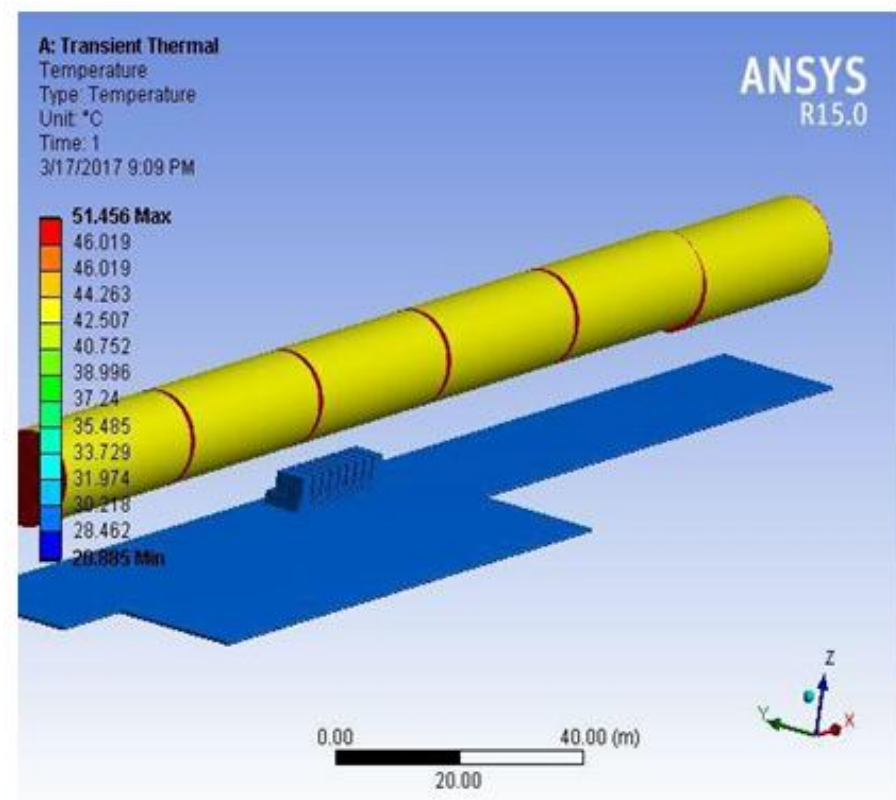

Figure 6 Simulated result of Aluminium material in ANSYS

From the figure of Aluminium, it is seen that the battery temperature is increased from $20^{\circ} \mathrm{C}$ and reaches up to $51^{\circ} \mathrm{C}$ 


\section{RESULT IN ANSYS WITH MATERIAL}

COPPER

The simulation is performed by assigning the boundary conditions of the Copper material. The simulated result is shown below

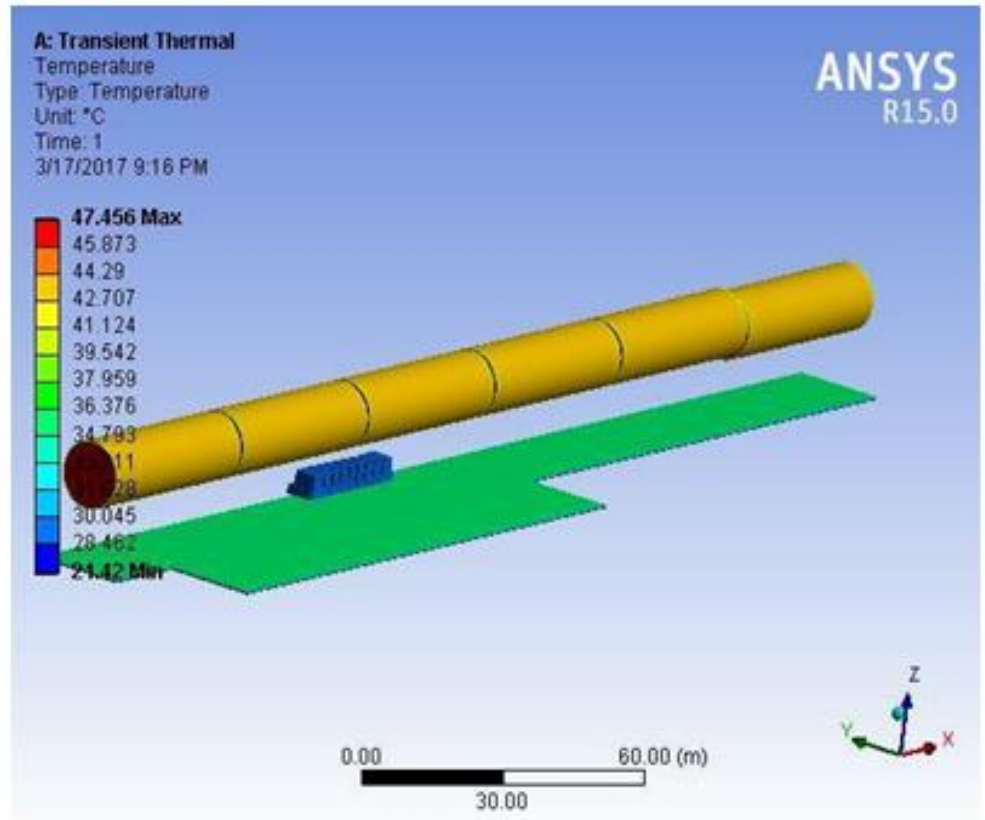

Figure 7 Simulated result of copper material in

From the figure of copper, it is seen that the battery temperature is increased from $21^{\circ} \mathrm{C}$ and reaches up to $47^{\circ} \mathrm{C}$ The below graph represents the temperature vs charging time of the materials that have been analyzed for thermal management.

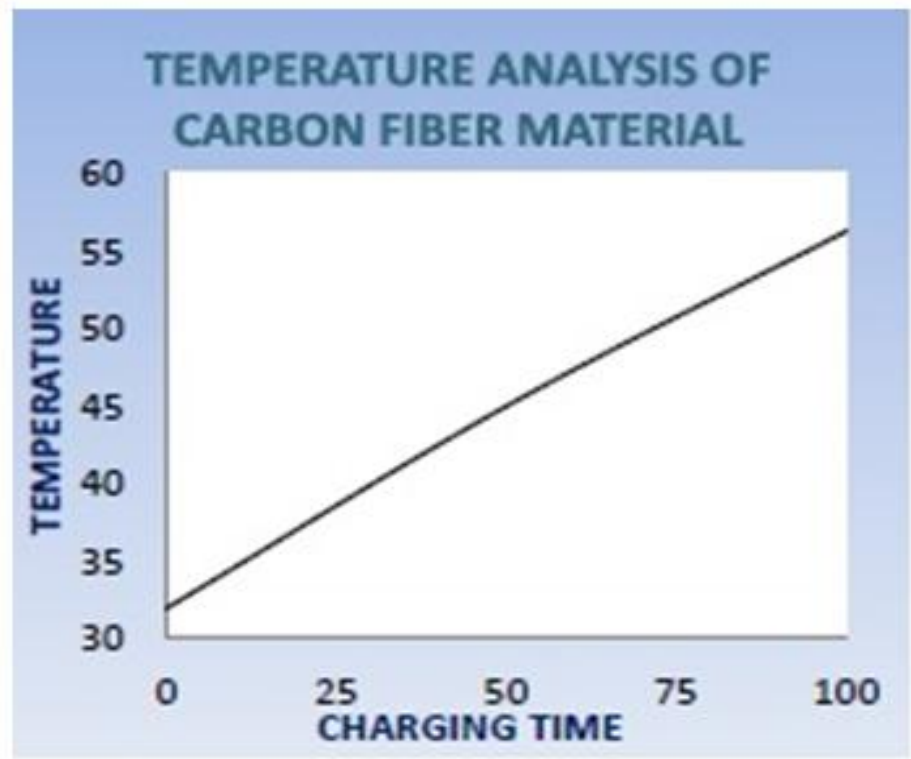

Figure 8 Temperature vs charging time of carbon fiber 


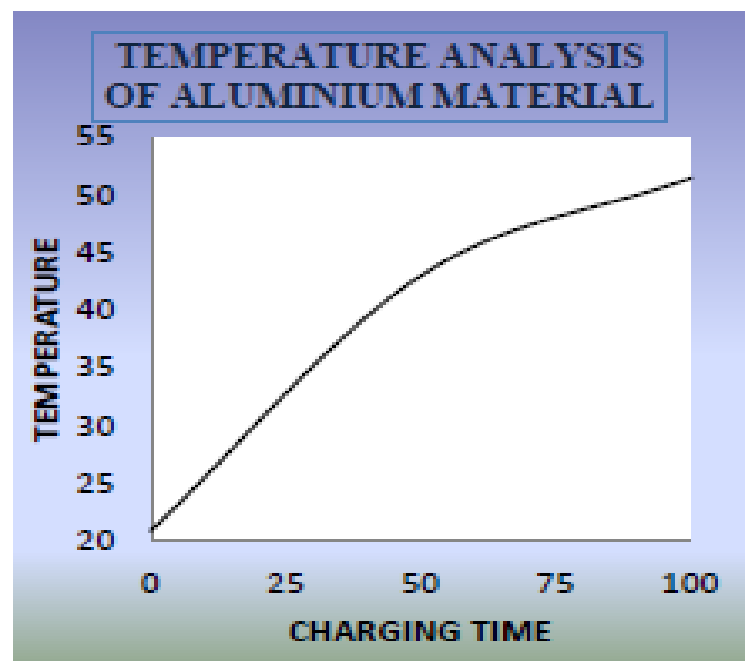

Figure 9 Temperature vs charging time of Aluminium

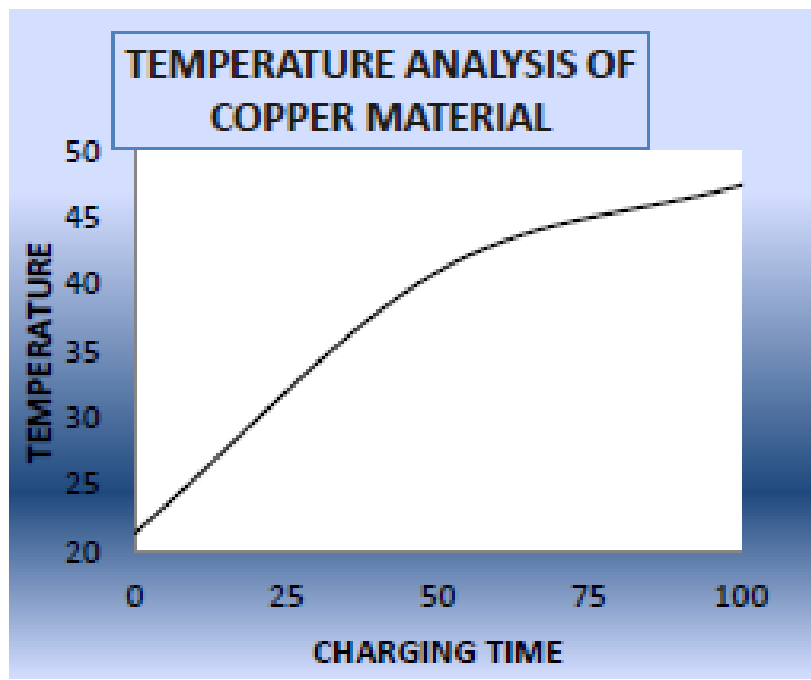

Figure 10 Temperature vs charging time of copper material

VI. Result Comparison

\begin{tabular}{|c|c|c|c|c|}
\hline $\begin{array}{c}\text { SL.N } \\
\mathbf{O}\end{array}$ & $\begin{array}{c}\text { MATERI } \\
\text { AL }\end{array}$ & SOC & SOC & SOC \\
\hline 01. & COPPER & $\begin{array}{c}21.42 \\
{ }^{\circ} \mathrm{C}\end{array}$ & $\begin{array}{c}41.23 \\
9^{\circ} \mathrm{C}\end{array}$ & $\begin{array}{c}47.45 \\
6{ }^{\circ} \mathrm{C}\end{array}$ \\
\hline 02. & ALUMINIUM & 20.88 & 43.01 & 51.45 \\
& & $5^{\circ} \mathrm{C}$ & ${ }^{\circ} \mathrm{C}$ & $6{ }^{\circ} \mathrm{C}$ \\
\hline 03. & & 31.97 & 45.10 & 56.28 \\
& CARBON FIBER & $1{ }^{\circ} \mathrm{C}$ & ${ }^{\circ} \mathrm{C}$ & $7{ }^{\circ} \mathrm{C}$ \\
\hline
\end{tabular}

Table 4 Comparison of materials with respect to SOC 


\section{Conclusion And Future Work}

From the results and output, it has been concluded that, Using copper as a material above the casing reduces the temperature significantly than other two materials i.e. carbon fiber and Aluminium. It also has high density and a good conductivity. So, using copper material is the best choice to reduce the temperature in a battery. A comparison of the composite materials with the analysis is done. The future work deals to still reduce the temperature by using both the combinations of fins and composite materials.

\section{Reference}

[1]. L.-R. Chen, J.-J. Chen, C.-M. Ho, S.-L. Wu, and D.-T. Shieh, "Improvement of Li-ion Battery Discharging Performance by Pulse and Sinusoidal Current Strategies," IEEE Trans. Ind. Electron., vol. 60, no. 12, pp. 5620-5628, Dec. 2013.

[2]. B. D. Valle, C. T. Wentz, and R. Sarpeshkar, "An Area and Power-Efficient Analog Li-Ion Battery Charger Circuit," IEEE Trans. Biomedical Circuits and Systems, vol. 5, no. 2, pp. 131-137, Apr. 2011.

[3]. Yoshiyasu Saito, Masahiro Shikano, Hironori Kobayashi, Heat generation behavior during charging and discharging of Lithium-ion batteries after long time storage, Vol.224:294-299,15 December 2013

[4]. Githin K.Prasad, Christopher D.Rahn, Model-based identification of aging parameters in Lithium-ion batteries, Vol.232:79-85,15 June 2013

[5]. A Mills, S Al-Hallaj Simulation of passive thermal management system for Lithium-ion battery packs, Journal of power sources,2005Elsevier 